\title{
MANAGERIAL EVALUATION OF THE LOGISTICS PERFORMANCE AND ITS DEPENDENCIES ON ECONOMIES IN SELECTED COUNTRIES
}

\author{
Alexandra Filová ${ }^{1, \mathrm{a}, *}$ and Veronika Hrdá ${ }^{2, \mathrm{~b}}$ \\ ${ }^{1}$ Faculty of Economics and Management, Slovak University of Agriculture in Nitra, Tr. A. Hlinku 2, \\ 94976 Nitra, Slovakia \\ ${ }^{2}$ Faculty of Economics and Management, Slovak University of Agriculture in Nitra, Tr. A. Hlinku 2, \\ 94976 Nitra, Slovakia \\ aalexandra.filova@uniag.sk, bveronika.hrda@uniag.sk
}

Cite as: Filová, A., Hrdá, V. (2021). Managerial evaluation of the logistics performance and its dependencies on economies in selected countries. Ekonomicko-manazerske spektrum, 15(1), 15-27.

Available at: dx.doi.org/10.26552/ems.2021.1.15-27

Received: 30 September 2020; Received in revised form: 6 February 2021; Accepted: 21 February 2021; Available online: 9 March 2021

\begin{abstract}
The objective of the paper is managerial evaluation of the level of logistics on individual continents and to find out dependence between the level of logistic systems and the level of GDP in the selected countries of the world. To evaluate logistics, we used the Logistics Performance Index and its six categories (customs clearance, infrastructure, international shipment, logistic competencies, monitoring shipment, and satisfaction). The index of gross domestic product was shown per capita and in constant U.S. dollars for 2010. The analyzed period was the years 2010, 2012, 2014, 2016, and 2018. Together, we analyzed 134 countries from five of the world's continents. Results are provided separately for the European countries and the Slovak Republic. To find out mutual linear dependence, we used the correlation coefficient. From the results of the research, it is clear that there is a connection between the variables LPI and GDP and thus that there exists a direct linear dependence. Only in one case, that of the African continent in 2018, was the coefficient of correlation close to zero and we had to state that the variables were not linearly dependent. For most resulting values of the correlation coefficient, we found only slight linear dependence. The exception was the countries of Australia and Oceania, where a strong dependence was found for all the years in question. This kind of analysis has significance primarily on the macroeconomic level. The individual countries can investigate, evaluate, and consequently improve their respective logistic systems and services. Understanding and decomposing the components of trade and logistics performance can help countries improve freight transport efficiency and identify where international cooperation could help overcome barriers.
\end{abstract}

Keywords: LPI; GDP; correlation; economic growth; managerial evaluation

JEL Classification: F1; O52; R4

\section{Introduction}

Due to globalization and internationalization, logistics is becoming more and more open. Beysenbaev and Dus (2020) state that "modern logistics is greatly influenced by the processes 
of globalization and internationalization. In the rapidly developing process of economy globalization, transportation management issues are of great importance". (Cui et al., 2020) It is hardly enough to consider only the challenges and problems within one specific country, rather, it is important to deal with the questions arising from the diversity and differences among countries or continents. Internationalization on the African continent, for example, is mentioned in the articles by Boso et al. (2019), and Warmeling and et al. (2020) with the claim that "there has been a marked increase in the internationalization activities of African firms over the last two decades or so." Roque et al. (2019) also mention that "the growing trend for globalization changes the way companies organize themselves and their way of acting, and impels them to consider the development of their activities in the international trade". As for internationalization, they find that "the internationalization is positively related to corporate social responsibility scores". Abyad (2017) and Weissova (2017) say that "globalization has impacted project management profoundly, and has only reinforced the trend toward adoption of the project mode of work organization. Globalization in project management means among other matters more projects executed in the multi-cultural environment," while Prashantham et al. (2017) state that "networks created as a by-product of globalization facilitate various forms of entrepreneurship." Anderton (2019) and Wrede and Dauth (2020) also state that "next to international operations, firms and their management teams are also challenged by intensifying global competition and rapid technological advancement, which places heightened demands on firms' innovativeness." (Benhabib et al., 2019)

Negative impacts of globalization: According to Lee et al. (2017) and Kozakova et al. (2021) "the most of the partial effects of globalization are positive for a poor performing economy (in terms of the levels of education, initial income, and globalization), while the partial effects are negative for those of a better performing economy." Cuervo-Cazurra et al. (2018) and Kobis et al. (2021) argue that "internationalization has a positive impact on the performance of emerging market firms". On the other hand, Debellis et al. (2021) state that "in the current fiercely globalized market where new technologies and disruptive business models are relentlessly emerging, any firm is more vulnerable. Going beyond domestic borders to explore opportunities and exploit non-location bound firm-specific advantages at the global level has thus become imperative to stay ahead of competitors." (Zhang et al., 2021)

Wood et al. (2012) indicates that "in international logistics there are many different parties: buyers, sellers, transporters, intermediaries and sometimes even the government.", while Fugate et al. (2012) state that "global supply chain managers are faced with operational challenges due to emerging factors such as the lengthening of supply chains, worldwide sourcing, and the necessity for mass-customized manufacturing." The authors Bugarčić et al. (2020) claim that "the volume of international trade heavily depends on factors facilitating trade and contributing to reducing its costs. The importance of international logistics as trade facilitator is increasingly emphasized in the literature." However, Grinevich et al. (2019) and Gani (2017) say that "the continuous growth in world trade depends on the efficiency of trade support structures such as the logistics services."

That is why the so-called Logistics Performance Index was created, sometimes used in the form of the abbreviation LPI. The World Bank describes the index as follows: "It is an interactive comparison tool created with the aim to help countries identify challenges and opportunities they face within performance of business logistics. The index states what they can do to improve their effectiveness. LPI is based on the world research of field operators (including global shippers and express transporters), who provide feedback on logistic acceptance of countries in which they operate and countries they do business with. They connect deep knowledge from the given countries with qualified qualitative evaluations of the 
countries where they operate and experience from the global logistic environment. Feedback from the operators is enhanced by quantitative data about effectiveness of key components of logistic chain of the given country. LPI therefore consists of qualitative as well as quantitative data. It helps to build profiles of logistic friendliness for the countries. It measures effectiveness in logistic supplier chain in the country, whereas it offers two different points of view: international and domestic." Martí et al. (2017) add that "logistics and transport increasingly play a pivotal role in international trade relations. (Zhang and Dai, 2020) The Logistics Performance Index measures the on-the-ground efficiency of trade supply chains or logistics performance." Rezaei et al. (2018) focus more closely on the components of LPI and point out certain shortcomings in its methodology in their research. The authors state that "to measures the performance of countries in terms of logistics, in 2007 the World Bank created the Logistics Performance Index (LPI), which uses six core indicators to rank countries with regard to their overall logistics performance. In the past decade, the LPI has been widely used by policymakers and researchers to formulate measures on logistics and freight transportation. At the moment, however, the different indicators are all regarded as being equally important when the overall index score is calculated, which seems highly unlikely within the complex system of logistics." A similar opinion has been put forward by Beysenbaev and Dus (2020) who claim that "the Logistics Performance Index is based on a global survey of logistics experts, which can be biased towards a subjective view on different countries' logistics systems, which leads to a potentially skewed rating." The authors suggest to modify the index so that it qualitatively and quantitatively represent a more objective point of view on logistic systems and subsystems of the countries based on international statistical data. (Rawas, and Iyer, 2013)

Despite of the aforementioned opinions, we can state that LPI is the only readily available comprehensive tool to provide general information about the quality of the world's logistic systems. By collecting data for so many countries, it serves as an important source of information for research in the field. That is why we decided to use primarily LPI-based data in the present study. The objective of the paper is not to evaluate credibility and quality of the index itself but rather to use it for further research and analysis. A similar approach was opted for in 2015 by Civelek et al. (2015), who were looking for a relationship between LPI, the index of global competitiveness (GCI) and gross domestic product (GDP). They focused on the analysis for the years 2007, 2010, 2012, and 2014 and consider LPI to be a useful and instructive tool, saying that "LPI is a most important indicator to understand and compare logistics performance of the countries. Comparing domestic sources, LPI is more reliable because in some countries finding data about market size, the number of existing firms, employment, and revenue in logistic sector is difficult for researchers." The same approach was taken by Roy et al. (2018) who state that "given the lack of studies bringing insights on logistics performance in the backdrop of trade logistics from the perspective of nation as a whole-this paper recognizes the LPI dataset as an account of rich country-level data with harbored insights on logistics performance“.

\section{Methodology}

\section{Countries and the analyzed period}

We included 134 countries of the world in our research and gathered primary data specifically from:

- 37 countries of Europe (out of which: 27 countries were in the EU and 10 countries not in the EU), 
- 29 countries of Africa (out of which: 6 countries were from Central Africa, 6 countries from East Africa, 11 countries from West Africa, 5 countries from North Africa and 1 country from South Africa),

- 24 countries from the Americas (out of which: 5 countries were from Central America, 2 countries from North America, 11 countries from South America and 6 countries from the Caribbean),

- 39 countries of Asia (out of which: 4 countries were from Central Asia, 6 countries from East Asia, 6 countries from South Asia, 1 country from North Asia, 8 countries from Southeast Asia and 14 countries from West Asia),

- 5 countries of Australia and Oceania (out of which 4 countries were from Oceania).

The analysis was realized for the years 2018, 2016, 2014, 2012, and 2010, the years for which LPI was available ${ }^{1}$.

\section{The Logistics Performance Index}

The main source for primary data for the index was the World Bank. The individual components for LPI were identified by the World Bank as follows:

- Customs clearance-effectiveness of procedures (i.e. speed, simplicity, and predictability of formalities) by the organs of border control, including customs.

- Infrastructure-quality of business and transport infrastructure (e.g. harbors, railroads, roads, information technologies, etc.).

- International shipment-simplicity of arranging shipments for competitive prices.

- Logistic competences-quality and availability of logistic services (e.g. operators of transport, customer service, etc.)

- Monitoring the shipment-possibility and quality of monitoring movement of shipment.

- Satisfaction-satisfaction with shipment to the destination within the planned or expected time of shipment.

\section{Gross Domestic Product}

The main source for primary GDP data was the World Bank which specifies that "GDP per capita is gross domestic product divided by midyear population. GDP is the sum of gross value added by all resident producers in the economy plus any product taxes and minus any subsidies not included in the value of the products. It is calculated without making deductions for depreciation of fabricated assets or for depletion and degradation of natural resources. Data are in constant 2010 U.S. dollars."

\section{Statistical analysis}

To determine dependences of the primary data, we computed the correlation coefficient between two elements of the statistical set (marked as $r(x, y)$ ). The $x$ variable stands for the logistics performance index, while the y variable represents gross domestic product per capita expressed in U.S. dollars. The value of the correlation coefficient expresses linear level of dependence between the variables $x$ and $y$ with its value ranging from -1 to 1 . We assume that if

- $|r(x, y)| \leq 0,3$, the correlation dependence is weak,

- $0,3<|r(x, y) \leq 0,8|$, the correlation dependence is slight,

${ }^{1}$ Note: LPI is calculated in approximately 165 countries. We included only 134 countries because not every country had the coefficient determined for all the monitored years, i.e., 2018, 2016, 2014, 2012, and 2010. 
- $|r(x, y)|>0,8$, the correlation dependence is strong.

The scientific hypothesis is:

The Logistics Performance Index is positively influenced by gross domestic product.

\section{Results}

In 2018, the highest value of LPI was reached: 4.20 points. Seven countries passed the limit of four points, five of which were EU countries (Austria, Belgium, Germany, Netherlands, and Sweden); the other two were Singapore and Japan.

Table 1: Countries for individual continents which reached the highest and the lowest coefficient of LPI in 2018

\begin{tabular}{lll}
\hline Continents & Countries & LPI \\
\hline \multirow{2}{*}{ Europe } & Germany & 4.20 \\
\multirow{2}{*}{ America } & Moldova & 2.46 \\
\multirow{2}{*}{ Africa } & United States & 3.89 \\
\multirow{2}{*}{ Asia } & Haiti & 2.11 \\
\multirow{2}{*}{ Australia and Oceania } & South Africa & 3.38 \\
& Angola & 2.05 \\
& Japan & 4.03 \\
\hline
\end{tabular}

Source: World Bank, International LPI - Gloval Rankings (2018, 2020)

In 2018, only one country had an LPI of less than two points (see Table 1). Seventy-nine countries ranged between two and three points, twenty-seven of which were African countries. Forty-seven countries had between three and four points, most of them from the European continent.

The difference between the LPI values for 2018 for the best and the worst rated countries was 2.25 points. As for continents, the best average values were found in Europe.

Figure 1: Comparison of reahced values of LPI and its components between countries with the highest and the lowest value and Slovakia in 2018

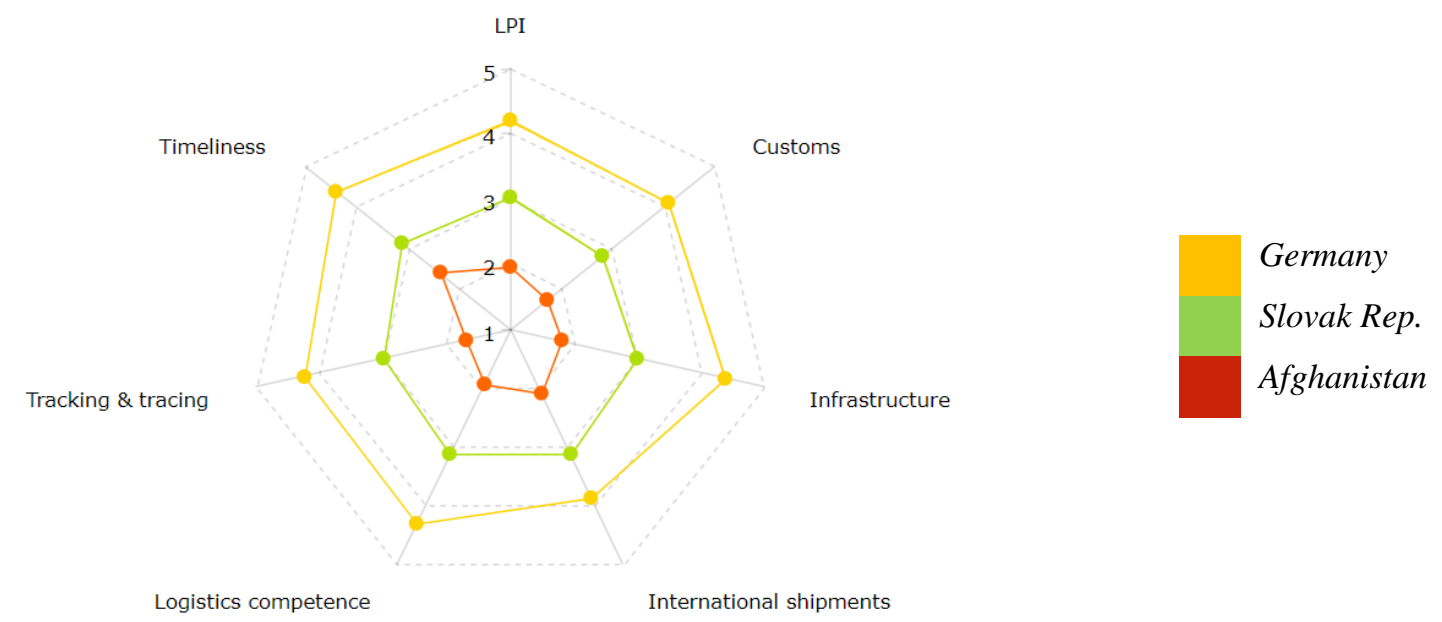

Source: World Bank, International Scorecard (2020)

Figure 1 shows the values of LPI and its six components or categories for countries with the best score (Germany) and the worst score (Afghanistan), with Slovakia's rates added for scale. We can see that the differences in values between the compared countries are significant. 
Table 2 shows that mutual linear dependence between the monitored variables is positive, i.e., higher values of LPI correspond to higher GDP in the six analyzed areas. The value of correlation for Europe and Asia was lower than that found for the whole set, i.e., the world. On the contrary, America, Australia, and Oceania had higher correlation coefficient than the whole set. Africa is the only analyzed continent for which we can state that there is no linear dependence between LPI and GDP. An interesting fact is that the African countries reached on average the worst possible score of LPI (2.5 points) and the lowest values of GDP per capita (2,307.91 U.S. dollars). The African continent also had the lowest LPI range between the top and the bottom value (1.33 points), showing the lowest relative difference between applied logistic systems. For all other monitored areas, the level of dependence was slight or strong (see Table 2).

Table 2: Results of correlation coefficient for individual continents in 2018

\begin{tabular}{lll}
\hline Continents & Correlation coefficient & Level of dependence \\
\hline Europe & 0.67471995 & Slight \\
Out of which EU & 0.57621989 & Slight \\
America & 0.77669636 & Slight \\
Africa & 0.05765796 & Negligible \\
Asia & 0.74653707 & Slight \\
Australia and Oceania & 0.93399084 & Strong \\
World & 0.77155319 & Slight \\
\hline
\end{tabular}

Source: own elaboration based on data World Bank, GDP per capita (2010) and World Bank, International LPI - Global Rankings $(2018,2020)$

In 2016, the highest value of LPI reached was 4.23 points. Nine countries reached values for more than four points, six of which were from the EU (Austria, Belgium, Germany, Luxembourg, Netherlands, and Sweden), the remaining three being Hong Kong, Singapore, and the United Kingdom.

Table 3: Countries of individual continents reaching the highest and the lowest LPI coefficient in 2016

\begin{tabular}{lll}
\hline Continents & Countries & LPI \\
\hline \multirow{2}{*}{ Europe } & Germany & 4.23 \\
& Montenegro & 2.38 \\
America & United States & 3.99 \\
\multirow{2}{*}{ Africa } & Haiti & 1.72 \\
\multirow{2}{*}{ Asia } & South Africa & 3.78 \\
\multirow{2}{*}{ Australia and Oceania } & Madagascar & 2.15 \\
& Singapore & 4.14 \\
\hline
\end{tabular}

Source: World Bank, International LPI - Global Rankings (2018, 2020)

In 2016, two countries had LPI lower than two points (Haiti and Syrian Arab Republic). Seventy-six countries reached values ranging from two to three points, twenty-six of which were from Africa. Forty-seven countries had LPI of three to four points, most of them on the European continent, with only three countries from Africa.

The total spread of the 2016 LPI values was 2.51 points, which represents the highest difference of the six analyzed years, we can therefore state that the differences between the countries deepened in 2016. The highest LPI values were once again found in Europe.

Figure 2 shows the Syrian Arab Republic having the biggest problems with four of the categories measured by LPI, namely: customs (only 1.11 points), infrastructure (1.24 points), international shipments (1.36 points), and logistics competence (1.39 points). 
Germany's worst rating was for the area of international shipments (3.86 points). For all the other categories, Germany ranked over four points. Apart from Germany, countries with five out of six categories rated at over four points were Belgium, Hong Kong, Luxembourg, Netherlands, Singapore, and Sweden. The highest value of 4.8 was Luxembourg's rating for timeliness.

Figure 2: Comparison of reached values of LPI and its components between the countries with the highest and the lowest value and Slovakia in 2016

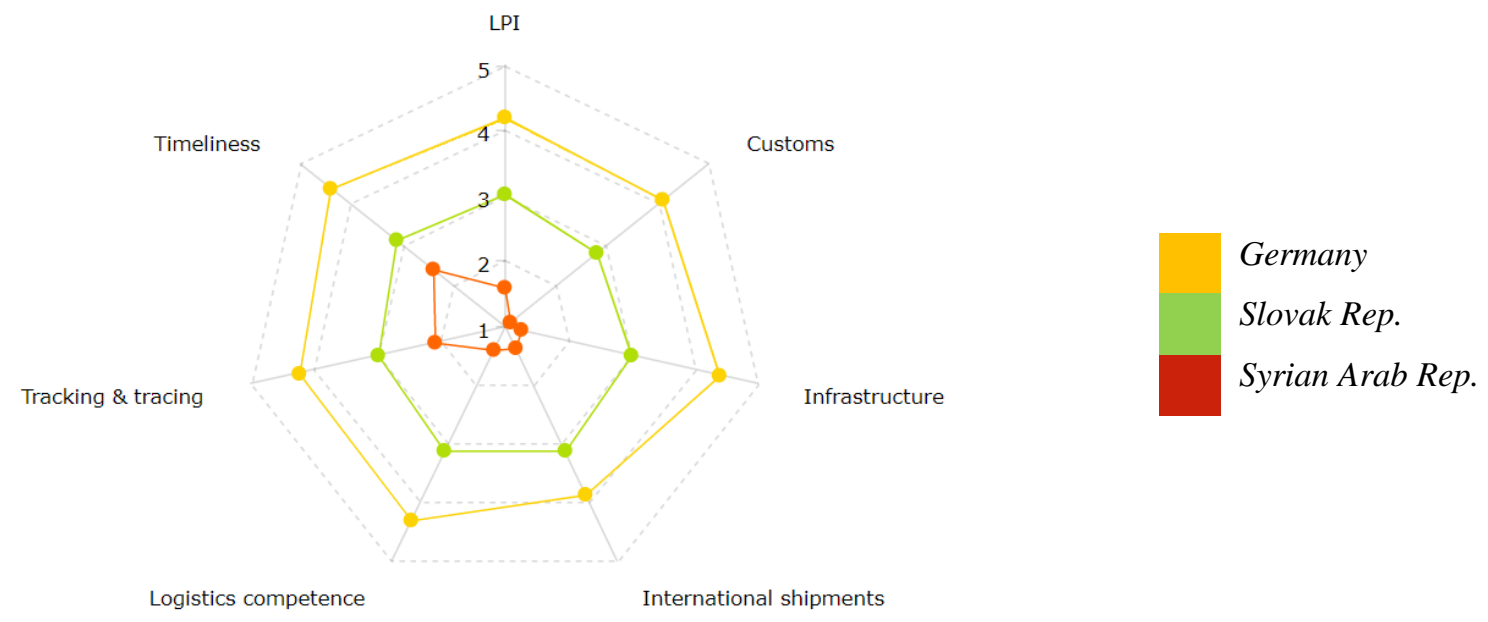

Source: World Bank, International Scorecard (2020)

Table 4: Results of correlation coefficient fir individual continents in 2016

\begin{tabular}{lll} 
Continents & Correlation coefficient & Level of dependence \\
\hline Europe & 0.76185722 & Slight \\
Out of which EU & 0.7533651 & Slight \\
America & 0.80857312 & Strong \\
Africa & 0.21178846 & Weak \\
Asia & 0.7365844 & Slight \\
Australia and Oceania & 0.98960782 & Strong \\
World & 0.7841315 & Slight
\end{tabular}

Source: own elaboration based on data World Bank, GDP per capita (2010) and World Bank, International LPI - Global Rankings $(2018,2020)$

Table 4 shows that mutual linear dependence between the monitored variables is positive in all the monitored areas. The level of dependence is different from the previous analyzed period of 2018 (see Table 2). In 2016, we record two areas with strong level of linear dependence, namely America and Australia and Oceania. The most significant change happened in Africa, where we can now speak of mutual dependence between the monitored indicators, although its level remains low. In 2016, Africa was not the continent with the lowest spread between LPI values, the lowest difference being between the maximum and minimum values for Australia and Oceania (1.48 points).

In 2014, the highest value of LPI reached was 4.12 points. Only five countries reached values of over four points, three of which were EU countries (Belgium, Germany, and Netherlands), and the remaining two Singapore and the United Kingdom.

In 2014, only one country had LPI of less than two points (see Table 5). Seventy-five countries had values between two and three points, out of which twenty-seven were African, twenty were from the Asian continent, and nineteen from America. Fifty-three countries ranked 
between three and four points, most of which were from Europe, with only one country from Africa.

The 2014 LPI spread between the best and the worst ranked country was 2.24 points, which is less than in 2016 represents the lowest difference in the five analyzed years. The best average values were those of European countries, with the European average LPI of 3.45 points. On the contrary, the lowest average values were recorded in Africa, with the continent's average LPI of 2.50 points.

Table 5: Countries for individual continents which reached the highest and the lowest LPI coefficient in 2014

\begin{tabular}{lll}
\hline Continents & Countries & LPI \\
\hline \multirow{2}{*}{ Europe } & Germany & 4.12 \\
& Macedonia, FYR & 2.50 \\
America & United States & 3.92 \\
\multirow{2}{*}{ Africa } & Cuba & 2.18 \\
\multirow{2}{*}{ Asia } & South Africa & 3.43 \\
& Congo, Dem. Rep. & 1.88 \\
\multirow{2}{*}{ Australia and Oceania } & Singapore & 4.00 \\
& Afghanistan & 2.07 \\
\hline
\end{tabular}

Source: World Bank, International LPI - Global Rankings (2018, 2020)

In 2014, the lowest LPI rating was that of the Democratic Republic of the Congo. Compared to 2016, we can see that the DRC had lower variations in the values of the individual monitored categories, just like the Syrian Arab Republic. Germany has once again the lowest value in the area of international shipments (3.74 points). Much like in 2016 and 2018, Germany was rated over four points in the remaining categories, with no other country achieving a similar result. The highest value in a single category was Luxembourg's 4.71 points in timeliness. An interesting fact is that Luxembourg's rating in the remaining categories dropped substantially, amounting to the overall LPI of 3.95 points.

Figure 3: Comparison of reached values of LPI and its components between the countries with the highest and the lowest values and Slovakia in 2014

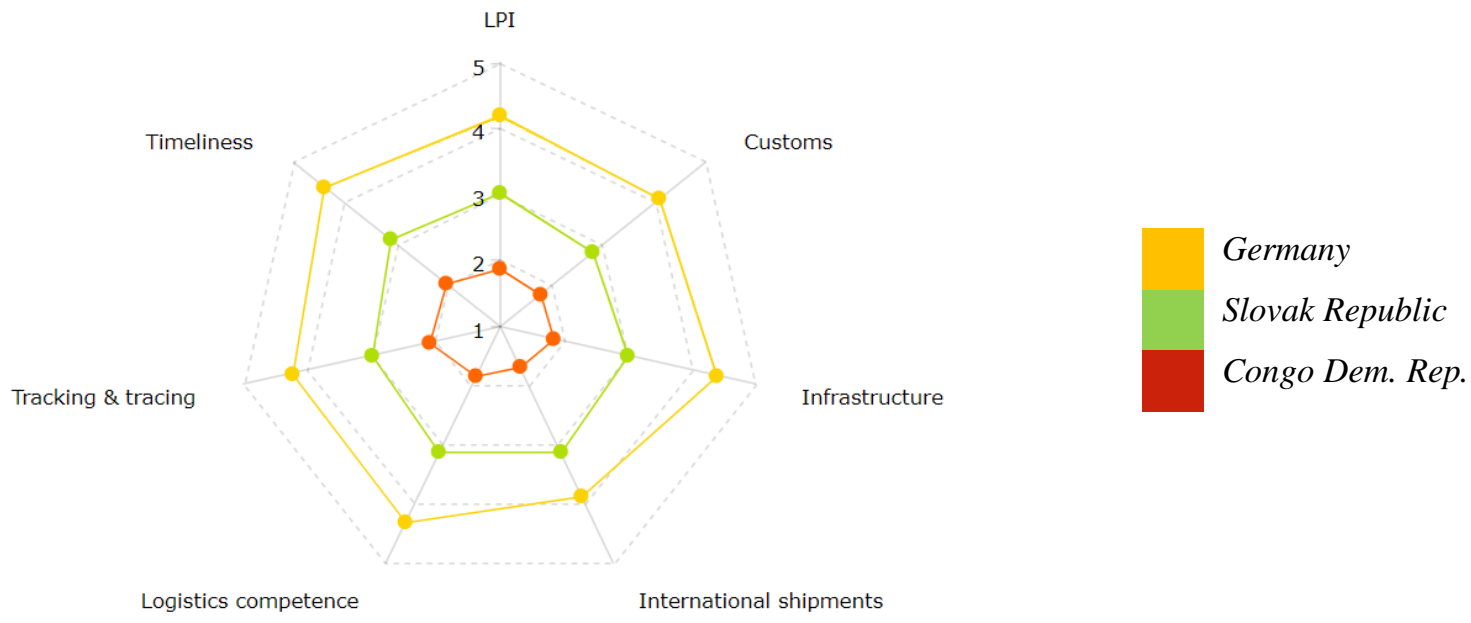

Source: World Bank, International Scorecard (2020)

Table 6 shows that mutual linear dependence between the monitored variables is positive in all the monitored categories, just like in 2016. We can state that in comparison to 2016 there is a similar level of mutual dependence (see Table 4 and Table 6). In 2014, we record two continents with strong level of linear dependence, namely America and Australia and Oceania. 
Weak level of mutual dependence is seen in Africa. The region in which we see the lowest LPI value spread is Australia and Oceania (1.38 points).

Overall, we can say that the years 2014 and 2016 were, with respect to the monitored ratings and dependences, very similar and we do not record any dramatic changes and differences between them.

Table 6: Results of correlation coefficient for individual continents in 2014

\begin{tabular}{lll}
\hline Continents & Correlation coefficient & Level of dependence \\
\hline Europe & 0.773553 & Slight \\
Out of which EU & 0.729769 & Slight \\
America & 0.825017 & Strong \\
Africa & 0.236725 & Weak \\
Asia & 0.700984 & Slight \\
Australia and Oceania & 0.978733 & Strong \\
World & 0.789614 & Slight \\
\hline
\end{tabular}

Source: own elaboration based on data World Bank, GDP per capita (2010) and World Bank, International LPI - Global Rankings $(2018,2020)$

In 2012, the country with the highest level of LPI was Singapore, i.e.an Asian country. For the whole monitored period it is the only case when the top score was not held by a European country. Germany, which topped the list in all other years, placed third in 2012 with 4.03 points, below Finland (4.05 points). Of the remaining European countries, only Denmark and Netherlands scored more than four points, while Singapore and Hong Kong held the same distinction among non-European countries.

In 2012, only one country scored lower than two points (see Table 7). Eighty countries scored between two and three points, twenty-six of these being African, twenty-three Asian, eighteen from the Americas, and ten from Europe (mostly non-EU countries). Forty-seven countries scored between three and four points, most of them European. Two African nations, Tunisia and South Africa, scored over three points.

The 2012 total LPI value spread was 2.33.

Table 7: Countries for individual continents which reached the highest and the lowest coefficient of LPI in 2012

\begin{tabular}{lll} 
Continents & Countries & LPI \\
\hline \multirow{2}{*}{ Europe } & Finland & 4.05 \\
& Moldova & 2.33 \\
America & United States & 3.93 \\
& Haiti & 2.03 \\
Africa & South Africa & 3.67 \\
& Djibouti & 1.80 \\
Asia & Singapore & 4.13 \\
& Nepal & 2.04 \\
Australia and Oceania & Australia & 3.73 \\
& Papua New Guinea & 2.38
\end{tabular}

Source: World Bank, International LPI - Global Rankings (2018, 2020)

An interesting fact shown in Figure 4 is that Singapore (just like Germany) has lowest scores in the category of International shipments (3.99 points). The same situation, from a different point of view, can be seen with Djibouti. This country, just like all the other mentioned countries with the lowest values of LPI, reaches the best score in the category of timeliness (2.19 points), the only area in which it score more than two points. 
Figure 4: Comparison of reached values of LPI and its components between the countries with the highest and the lowest value and Slovakia in 2012

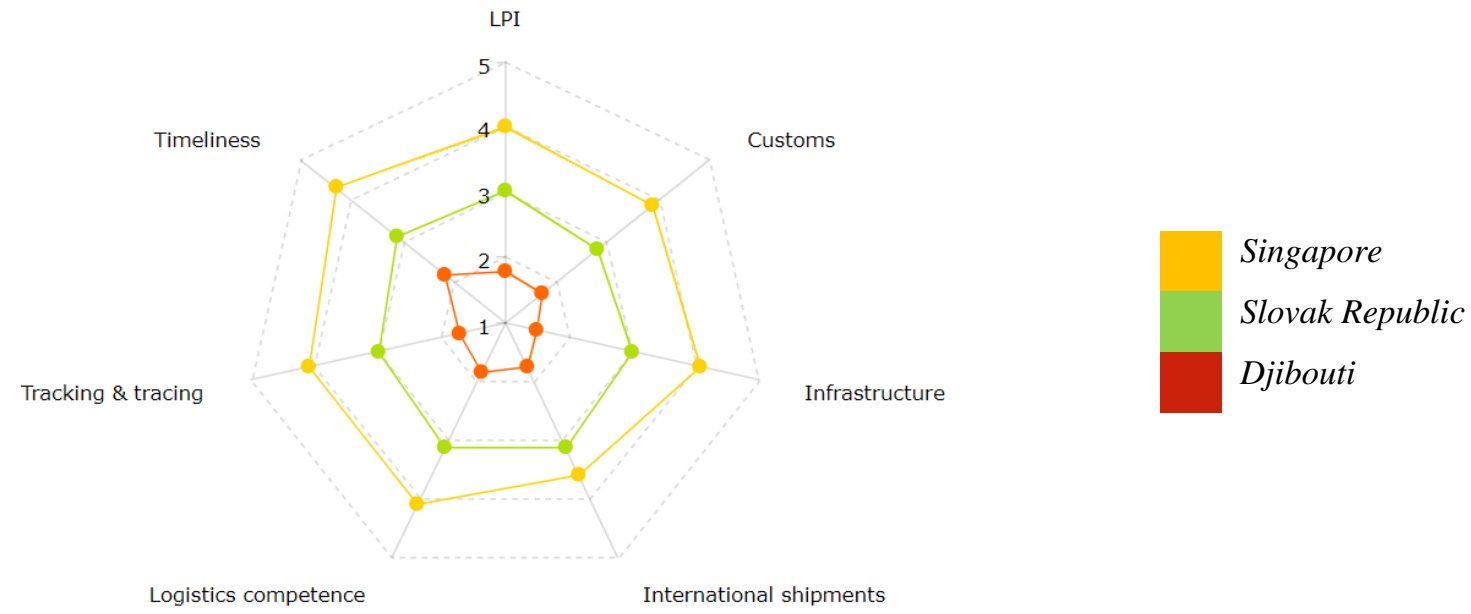

Source: World Bank, International Scorecard (2020)

In 2012, Singapore scored lowest in the area of international shipments (3.99 points), much like Germany in 2014, 2016, and 2018, and, also much like Germany, Singapore scored over four points in the remaining categories. A similar result of five out of six categories with values over four points, was achieved by Hong Kong.

The highest recorded value was Singapore's 4.39 points in the timeliness category, where Luxembourg scored 4.19 points. Apart from them, twenty-three further countries scored over four points in this area.

Just like in 2014 and 2016, there were no significant changes in mutual linear dependence between the variables for the individual continents. Strong dependence can be seen in the case of America and Australia and Oceania. Compared to the other monitored years, the level of linear dependence in 2012 was the strongest in case of Australia and Oceania, i.e., the correlation coefficient reached the highest value.

Weak mutual dependence on the other hand was recorded in African countries, with only slight dependence for the rest.

Table 8: Results of correlation coefficient for individual continents in 2012

\begin{tabular}{lll} 
Continents & Correlation coefficient & Level of dependence \\
\hline Europe & 0.764691 & Slight \\
Out of which EU & 0.747185 & Slight \\
America & 0.810621 & Strong \\
Africa & 0.208328 & Weak \\
Asia & 0.677728 & Slight \\
Australia and Oceania & 0.992676 & Strong \\
World & 0.769543 & Slight
\end{tabular}

Source: own elaboration based on data World Bank, GDP per capita (2010) and World Bank, International LPI - Global Rankings $(2018,2020)$

In 2010, Germany once again held the top spot with the LPI value of 4.11 points. Three other countries scored more than four points (Netherlands, Sweden, and Singapore).

Table 9: Countries for individual continents which reached the highest and the lowest coefficient LPI in 2010

\begin{tabular}{lll}
\hline Continents & Countries & LPI \\
\hline \multirow{2}{*}{ Europe } & Germany & 4.11 \\
America & Moldova, Ukraine & 2.57 \\
& Canada & 387
\end{tabular}




\begin{tabular}{lll} 
& Cuba & 2.07 \\
Africa & South Africa & 3.46 \\
\multirow{2}{*}{ Asia } & Eritrea & 1.70 \\
\multirow{2}{*}{ Australia and Oceania } & Singapore & 4.09 \\
& Iraq & 2.11 \\
\hline
\end{tabular}

Source: World Bank, International LPI - Global Rankings (2018, 2020)

In 2010, only one country scored less than two points (see Table 9). Eighty-three countries reached values between two and three points, twenty-seven of which were from Africa, twentythree from the Asian continent, seventeen from the Americas, and thirteen from Europe (most of these being non-EU countries). Only twenty-eight countries scored between three and four points, most of these (twenty-one countries) were from the European continent. Among African countries, only South Africa scored more than three points (3.46 points).

The total 2010 LPI spread was 2.41.

Figure 5 shows that Eritrea reached more than two points (specifically 2.21) only in the area of Timeliness, with the other five categories below that level. Such low values for individual categories of LPI were not recorded by any other country. Relatively low values of LPI were also recorded by Cuba (2.07 points) and Rwanda (2.04 points). Cuba had three categories rated over two points (international shipments, timeliness, tracking and tracing), while Rwanda score more than two points in only two categories (international shipments, timeliness).

Figure 5: Comparison of reached values of LPI and its components between the countries with the highest and the lowest value and Slovakia in 2010

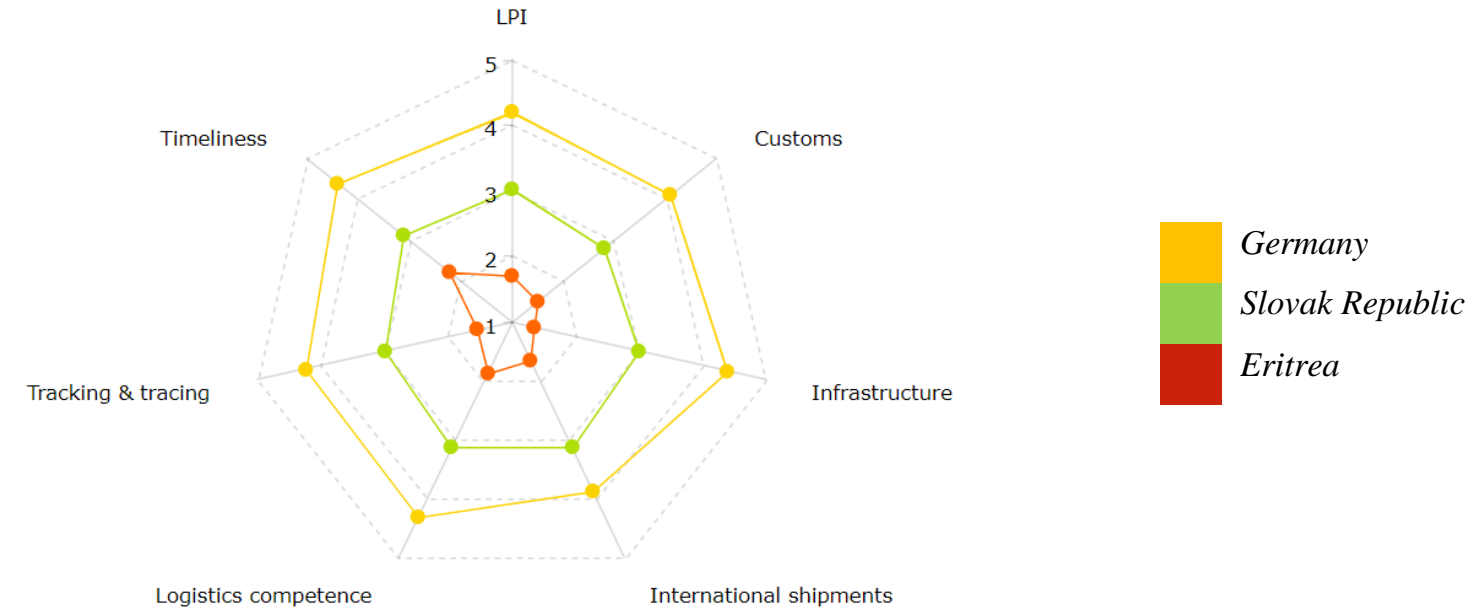

Source: World Bank, International Scorecard, 2020

Table 10: Results of correlation coefficient for individual continents in 2010

\begin{tabular}{lll} 
Continents & Correlation coefficient & Level of dependence \\
\hline Europe & 0.815555 & Strong \\
Out of which EU & 0.775788 & Slight \\
America & 0.802126 & Strong \\
Africa & 0.311314 & Slight \\
Asia & 0.632065 & Slight \\
Australia and Oceania & 0.975545 & Strong \\
World & 0.791264 & Slight
\end{tabular}

Source: own elaboration based on data World Bank, GDP per capita (2010) and World Bank, International LPI - Global Rankings (2018, 2020) 
Just like in 2018, 2016, and 2014, in 2010, Germany scored lowest in the area of timeliness (3.66 points). The highest recorded value of 4.58 points was scored by Luxembourg in the category of timeliness, the area which had the highest values overall for all of the monitored years. In particular, countries with higher total LPI appear to have less problems with timeliness. Compared to the other analyzed years, for 2010 we found out that three continents (Europe, America, Australia and Oceania) show strong mutual linear dependence between the monitored variables. For Africa, correlation in 2010 had the value of over 0.31 , which signifies slight dependence. This is probably why in 2010 we record the highest values of correlation for the whole monitored set of one hundred and thirty-four countries of the world (see Table 10).

\section{Discussion}

The paper attempts to answer the question of whether there is a mutual dependence between the coefficients of LPI and GDP per capita. It would be interesting to widen the research into other areas, e.g., finding correlation with the HDI (the Human Development Index) which according to the methodology of the Human Development Report is defined as the arithmetical average of its three partial indexes (life expectancy, education, and per capita income).

To sum up, Gokmenoglu et al. (2018) state that "economic growth is a necessary condition for human progress, but not sufficient in itself to guarantee it; therefore, other categories and determinants of human development must be investigated by researchers."

Another possibility could be finding correlations between LPI and indices reflecting income or expenditures of population, specifically annual net household income and expenditures per household member. Possibilities for further research are numerous.

\section{Conclusion}

Results of the research make it clear that there is a connection between the LPI and GDP, with direct linear dependence, i.e., we accept the scientific hypothesis that the Logistics Performance Index is positively influenced by gross domestic product.

Only in one case was the correlation coefficient close to zero and we had to conclude that the variables were not linearly dependent, the case of Africa in 2018. Most calculated values of the correlation coefficient showed slight linear dependence. The exception from this was the countries of Australia and Oceania, where we found strong dependence for all years in question.

From the analysis provided in the paper, we can state that the countries of the European continent reach the highest values of LPI (the average value of LPI for all years analyzed stayed above three points). On the contrary, the lowest values of LPI were recorded by African countries (the average value of LPI for did not exceed 2.55 points for any of the analyzed years).

\section{References}

Anderton, Ch. H. (2019). The political economy of defence. Journal of Economic Literature, 57(4), 1005-1007. Abyad, A. (2017). Globalization challenges in project management. Middle East Journal of Business, 12(4), 1019.

Benhabib, J., Liu, X., \& Wang, P. (2019). Financial markets, the real economy, and self- fulfilling uncertainties. Journal of Finance, 74(3), 1503-1557.

Beysenbaev, R., \& Dus, Y. (2020). Proposals for improving the logistics performance index. The Asian Journal of Shipping and Logistics, 36(1), 34-42.

Boso, N., Adeleye, I., Ibeh, K., \& Chizema, A. (2019). The internationalization of African firms: Opportunities, challenges, and risks. Thunderbird International Business Review, 61(1), 5-12.

Bugarčić, F., Skvarciany, V., \& Stanišić, N. (2020). Logistics performance index in international trade: Case of Central and Eastern European and Western Balkans countries. Business: Theory and Practice, 21(2), 452-459. 
Civelek, M., Uca, N., \& Çemberci, M. (30. May 2015). The mediator effect of logistics performance index on the relation between global competitiveness index and gross domestic product. European Scientific Journal, 11(13), 368-375.

Cuervo-Cazurra, A., Ciravegna, L., Melgarejo, M., \& Lopez, L. (February 2018). Home country uncertainty and the internationalization-performance relationship: Building an uncertainty management capability. Journal of World Business, 53(2), 209-221.

Cui, R., Li, M., \& Li, Q. (2020). Value of high-quality logistics: Evidence from a clash between SF express and Alibaba. Management Science, 66(9), 3879-3902.

Debellis, F., Rondi, E., Plakoyiannaki, E., \& De Massis, A. (2021). Riding the waves of family firm internationalization: A systematic literature review, integrative framework, and research agenda. Journal of World Business, 56(1), 101-144.

Fugate, B. S., Autry, C. W., Davis-Sramek, B., \& Germain, R. N. (2012). Does knowledge management facilitate logistics-based differentiation? The effect of global manufacturing reach. International Journal of Production Economics, 139(2), 496-509.

Gani, A. (2017). The logistics performance effect in international trade. The Asian Journal of Shipping and Logistics, 33(4), 279-288.

Gokmenoglu, K., Apinran, M. O., \& Taspinar, N. (2018). Impact of foreign direct investment on human development index in Nigeria. Business and Economics Research Journal, 9(1), 1-13.

Grinevich, V., Huber, F., Karatas-Ozkan, M., \& Yavuz, C. (2019). Green entrepreneurship in the sharing economy: Utilising multiplicity of institutional logics. Small Businesss Economics, 52(4), 859-876.

Kobis, N. C., Soraperra, I., \& Shalvi, S. (2021). The consequences of participating in the sharing economy: A transparency-based sharing framerwork. Journal of Management, 47(1), 317-343.

Kozakova, J., Urbanova, M., \& Savov, R. (2021). Factors influencing the extent of the ethical codes: Evidence from Slovakia. Journal of Risk and Financial Management, 14(1), 40.

Lee, C.-C., Lee, C.-C., \& Chiou, Y.-Y. (2017). Insurance activities, globalization, and economic growth: New methods, new evidence. Institutions and Money, 51, 155-170.

Martí, L., Martín, J., \& Puertas, R. (2017). A DEA-logistics performance index. Journal of Applied Economics, 20(1), 169-192.

Prashantham, S., Eranova, M., \& Couper, C. (2017). Globalization, entrepreneurship and paradox thinking. Asia Pacific Journal of Management, 35, 1-9.

Rawas, M. Y. A., \& Iyer, K. N. S. (2013). How do small firms possibly survive? A comparison study of marketing skills and logistics infrastructure of small and large wholesalers. International Business Review, 22(4), 687698.

Rezaei, J., van Roekel, W. S., \& Tavasszy, L. (2018). Measuring the relative importance of the logistics performance index indicators using Best Worst Method. Transport Policy, 68, 158-169.

Roque, A. F., Alves, M.-C., \& Raposo, M. L. (April 2019). Internationalization strategies revisited: Main models and approaches. IBIMA Business Review, 1-10.

Roy, V., Mitra, S., Chattopadhyay, M., \& Sahay, B. (2018). Facilitating the extraction of extended insights on logistics performance from the logistics performance index dataset: A two-stage methodological framework and its application. Research in Transportation Business and Management, 28, 23-32.

Wood, D., Barone, A., Murphy, P., \& Wardlow, D. (2012). International Logistics. Florence: Springer Science \& Business Media.

World Bank. (3. December 2020). GDP per capita (constant 2010 US\$). Available at: The World Bank Group: https://data.worldbank.org/indicator/NY.GDP.PCAP.KD

World Bank. (3. December 2020). International LPI - Global Rankings 2018. Available at: The World Bank Group: https://lpi.worldbank.org/international/global/2018

World Bank. (3. December 2020). International Scorecard. Available at: The World Bank Group: https://lpi.worldbank.org/international/scorecard

Wrede, M., \& Dauth, T. (June 2020). A temporal perspective on the relattionshop between top management team internationalization and firms innovativeness. Managerial and Decision Economics, 41(4), 542-561.

Warmelink, H., Koivisto, J., Mayer, I., Vesa, M., \& Hamari, J. (2020). Gamification of production and logistics operations: Status quo and future directions. Journal of Business Research, 106, 331-340.

Weissova, I. (2017). Applicability of selected predictive models in the Slovak companies. Proceedings of the 17th Annual Conference on Finance and Accounting. Prague, Czech Republic, 699-708.

Zhang, G., Wang, L., Guo, F., \& Yang, G. (2021). Does corporate internationalization affect corporate social responsibility? Evidence from China. Emerging Markets Review, 100794.

Zhang, B., \& Dai, W. (2020). Trend inflation and macroeconomic stability in a small open economy. Economic Modelling, 91, 769-778. 